\title{
Customer Satisfaction and Public Service Delivery: The Case of Dire Dawa Administration
}

\author{
Zewdu Teshome ${ }^{1} \quad$ Behailu Belete $^{2} \quad$ Girma Gizaw $^{3} \quad$ Muluken Mengiste $^{2}$ \\ 1.Principal Researcher and Research Team Leader at Dire Dawa Management and Kaizen Institute, Dire Dawa, \\ Ethiopia \\ 2.Principal Researcher at Dire Dawa Management and Kaizen Institute, Dire Dawa, Ethiopia \\ 3.Directorate Director at Dire Dawa Management and Kaizen Institute, Dire Dawa, Ethiopia
}

\begin{abstract}
The issue of service delivery is becoming a global concern that demands continuous reform to fit the turbulent environment and changing customer needs. Efficient and effective services delivery is now a prominent agenda of most countries including Ethiopia. The demand for effective and efficient delivery of services requires fundamental change involving both institutional and cultural changes. Hence, measuring the level of satisfaction provides an indication of how successful organizations are at providing services, and is taken as effective outcome measure. Several researches have been conducted on the subject matter; however, most of them were focusing on private sectors such as insurance, hotel, bank and the like. Few are studied on public service organizations. Moreover, so far no study has been conducted that critically analyzes the state of customer satisfaction on service delivery of public service organizations in Dire Dawa Administration. The purpose of this study is therefore to assess customer satisfaction on service delivery of public service organizations in Dire Dawa Administration. To this effect, four research questions were employed to guide the study. These were: 1) what are the levels of customer satisfaction of public service organizations in Dire Dawa Administration? 2) What are the extents of the service delivery process in public service organizations (in terms of Assurance, Reliability, Tangibility, Empathy, and Responsiveness)? 3) What are the relationships between service delivery dimensions and customer satisfaction? 4) What are the major problems that exist in the service delivery process of public service organizations in Dire Dawa Administration? In addition, two data gathering techniques: systematic random sampling and purposive sampling were used to obtain relevant data required for the study. In the primary data gathering technique, questionnaire that were designed and distributed to customers and employees were used. For further elaboration, key informant interviews were conducted with selected officials from the sample organizations. Secondary data from different sources were employed. The data gathered from both primary and secondary sources were analyzed and presented using descriptive and statistical methods such as means, frequencies, percentages, tables and charts. The results of the study indicated that the five service delivery dimensions and customer satisfaction were positively correlated; the general level of customer satisfaction and the service delivery dimensions were moderate. The major challenges in service delivery such as lack of skilled and experienced leadership, inability to lead and make decisions strategically, inconsistent follow up and monitoring, absence of regular consultation with customers and stakeholders, prevalence of corruption and rent seeking activities and behavior, lack of motivation and service mentality, ineffective automation, absence of timely revision of rules and regulations; lack of cooperation and integration among stakeholders, inefficient and inappropriate grievance handling systems, mismatch between demand and supply in water, health and electric services, and absence of conducting customer satisfaction surveys scientifically were thoroughly identified. Finally, based on the analysis and conclusions, possible recommendations were suggested for alleviating the major challenges of service delivery processes in the study area.
\end{abstract}

Key Terms: Customer Satisfaction, Service Delivery, Public Service Organizations.

DOI: $10.7176 /$ PPAR/10-7-02

Publication date:July $31^{\text {st }} 2020$

\section{Introduction}

The issue of service delivery is becoming a global concern that demands continuous reform to fit the dynamic environment and changing customer needs. Efficient and effective services delivery is now a prominent agenda of most countries including Ethiopia. The Ethiopian People's Revolutionary Democratic Front (EPRDF) has been taking different reform measures in the political, economic and social spheres. It has also taken comprehensive measures to restructure the civil service, one of which is the civil service reform. In the early 1990s, the government launched Civil Service Reform Program (CSRP). The reform has included five sub-programs, one of which is the service delivery and quality of service sub-program. The program is under the responsibility of the Office of the Prime Minister and is designed to improve the quality of service provided by public sector employees and includes the establishment of a complaint-handling mechanism. The program would have made civil service institutions follow an appropriate and improved system of service delivery so as to give service to the public in an effective, efficient, transparent and impartial manner. The employees of the civil service institutions have the responsibility 
and obligation to provide quality service to the public fairly, equitably, honestly, efficiently and effectively (Paulos, 2001).

Most of the civil service institutions in our country lack appropriate customer service policies, the institutional capacity and resources to cope with customer service challenges. Despite the efforts made by the Ethiopian government, the implementation of the civil service reform regarding the service delivery has faced many challenges. According to Yosef (2011) and Zerihun (2014), lack of cooperation from staff (since the reform is viewed as downsizing the work force), inadequate staff training and development, lack of enthusiasms and interest, lack of top management support, lack of motivation and communication of the vision and inadequate commitment to reform, lack of visionary leadership, and unclear accountability relationship between public service providers were the main challenges. These challenges may affect customers' satisfaction. Now a days, customer satisfaction has become a subject of great interest to organizations and researchers. Customer satisfaction is the individual's perception of the performance of the- product or service in relation to his or her expectations. The concept of customer satisfaction is a function of customer expectations. A customer whose experience falls below expectations will be dissatisfied. And customers whose expectations are exceeded will be very satisfied or delighted (Schiffman and Kanuk, 2005).

Recently, the government of Ethiopia has started introducing new ways of doing business under the civil service reform program to enhance the institutional capacity of the public service organizations. Following this initiative, nearly all public service organizations in Dire Dawa administration have implemented the reform program using Business Process Reengineering (BPR), Balanced Score Card (BSC), and other reform management tools, and complaint management system to enhance the service quality by reducing the negative effects of customer dissatisfaction. The city administration has been implementing the Business Process Reengineering for the last seven years. Besides, the public service organizations are attempting to provide services in accordance with the perceived standards set in their respective citizens' charter documents. However, it is observed that lack of customer satisfaction is one of the most important problems. The demand for effective and efficient delivery of services requires fundamental change involving both institutional and cultural changes. Hence, measuring the level of satisfaction provides an indication of how successful organizations are at providing services, and is taken as effective outcome measure. This study therefore aims to assess customer satisfaction on the service delivery of public service organizations in Dire Dawa Administration.

\subsection{Statement of the problem}

The problem of this research is induced by the need to empirically measure customer satisfaction on service delivery of selected public service organizations in Dire Dawa Administration. According to Benjamin (2012), public service organizations exist to provide services to the citizens, the private sector and other institutions. It is a well-known fact that service delivery by public service organizations is inundated with several challenges. Mohammed et al (2010), sited in Benjamin (2012), stated that public service organizations agree that customer service is one of the most important vital factors that contribute to the establishment of reputation and credibility among the public. They also argued that the public- complaint of long queues, poor service delivery and insufficient physical facilities might affect the image and level of service quality in the public sector.

Despite the efforts made by the government of Ethiopian, the service delivery and grievance handling system of most of the public service organizations are not in a position to fully satisfy large number of customers. Problems have been observed in delivering services to the public in a manner that is satisfying customers. According to Yoseph (2011), one of the major problems in the civil service institutions of Ethiopia was low service delivery systems which could lead to low efficiency of service delivery. Several researches have been conducted on the subject matter; however, most of them were focusing on private sectors such as insurance, hotel, bank and the like (Akalu, 2015; Ibraheem and Chinonso, 2015; Jayaraman et al, 2010). Few are studied on public service organizations like, Social Security Agency and Document Authentication and Registration Office, Customer Satisfaction in Land Delivery Service a case study of Bishoftu Town Administration, Service Delivery and Customer Satisfaction: the Case of Ethiopian Electric Power Corporation Eastern Addis Ababa Region Customer Service Centers, (Desta, 2008; Mohammed, 2008; Zeritu, 2010). Moreover, as far as the researchers' knowledge is concerned, there is no study so far conducted to investigate the state of customer satisfaction on service delivery of public service organizations in Dire Dawa Administration. Therefore, this research proposes to fill the gap in this regard by assessing customer satisfaction on service delivery of public service organizations in Dire Dawa Administration.

\subsection{Objectives of the Study}

The main objective of the study is to assess customer satisfaction on service delivery of public service organizations in Dire Dawa Administration. The study also tries to achieve the following specific objectives:

1. To measure the level of customer satisfaction of public service organizations in Dire Dawa Administration 
2. To assess the service delivery process of public service organizations in terms of service delivery dimension (Assurance, Reliability, Tangibility, Empathy, and Responsiveness)

3. To examine the relationship between service delivery dimension and customer satisfaction.

4. To find out major problems that exist in the service delivery process of public service organizations

\subsection{Research Questions}

1. What are the levels of customer satisfaction of public service organizations in Dire Dawa Administration?

2. What are the extents of the service delivery process in public service organizations (in terms of Assurance, Reliability, Tangibility, Empathy, and Responsiveness)?

3. What are the relationships between service delivery dimensions and customer satisfaction?

4. What are the major problems that exist in the service delivery process of public service organizations in Dire Dawa Administration?

\section{Literature Review}

\subsection{Definitions and Concepts of Service}

The service concept is adapted to the current society's life and is as old as the history of humans. Considered from this viewpoint, there is no generally accepted and complete definition of services. International Business Machine (IBM), in their ongoing research program Services science, lists a random selection of efforts to define services from the literatures and suggests that service is 'a provider-client interaction that creates and capture value (Yuan, 2013). In review of a wide variety of definitions Hermen (2009) summed it up when he said, "A service is an activity which has some element of intangibility associated with it which involves some interaction with customers or with property in their possession, and does not result in a transfer of ownership. A change in condition may occur and production of the service may or may not be closely associated with a physical product." In simple terms "Services are deeds, processes, and performances" (Jayaraman et al., 2010). However, in a more broader definition, Enyonam (2011), Benjamin (2012) and Biljana and Jusuf (2011) indicate that "services include all economic activities whose output is not a physical product, and is generally consumed at the time of production, and provides added value in forms such as convenience, amusement, timeliness, comfort, or health which are essentially intangible in nature". Ahmad (2011), on the other hand, defines services as "any act or performance that one party can offer to another that is essentially intangible and does not result in the ownership of anything". He affirms the view that "services are intangible, inseparable, variable and perishable and also added that services normally require more quality control, supplier- credibility, and adaptability". According to Gronroos (2000), services are "activities or series of activities of more or less intangible nature that normally, but not necessarily, take place in interactions between customer and service employees and/or physical resources or goods and/or systems of the service provider, which are provided as solutions to customer problems."

\subsection{Difference between goods and services}

Much has been made of the differences between goods and services based on variations in product characteristics (Abdelfattah, 2015). Likewise, Chich and I. Mang (2007); Prabha (2010), Amin and Nazmul (2008), in an attempt to differentiate between goods and services, indicate that goods and services should be distinguished on the basis of their attributes. They explain that "goods are tangible physical objects which can be created and transferred, and can exist over time and therefore can be stored and used later". According to their definition "services tend to be intangible, and unlike goods or manufactured products, are created and used simultaneously or near simultaneously. According to Besley and Maitreesh (2006), there are four major characteristics of services that greatly affect the design of marketing program and these are:-

Intangibility

Services are activities or benefits that are essentially intangible, cannot be prefabricated in advance and do not involve ownership of the title. The fix-it service such as mechanic, repairman, etc. and finally the value added service as the least tangible of all (Tessa et al., 2011). Because they are performances rather than objects, precise manufacturing specifications concerning uniform quality can rarely be set. Most services cannot be counted, measured, inventoried, tested and verified in advance of sale to assure quality (Parasuraman et al., 1985). Because service is not an object but a phenomenon; it is difficult for customers to evaluate the quality of services as they evaluate physical goods. Because of intangibility, the service firm may find it difficult to understand how customers perceive their services and evaluate service quality (Erkan et al., 2014).

\section{Heterogeneity}

Services, especially those with high labor content, are heterogeneous; their performance often varies from producer to producer, from customer to customer, and from day to day (Parasuraman et al., 1985). Inseparability

Production and consumption of many services are inseparable (Joan and Joseph, 2002, Gronroos, 2000, Mohammed, 2008). Services involve simultaneous production and consumption. Inseparability implies that service is simultaneously produced and consumed while physical goods are first produced, then sold and finally 
consumed. Inseparability of production and consumption often forces the involvement of the customer in the production process. Inseparability also means that the producer and the vendor often compromise one economic entity (Simon and Foresight, 2009). In labor intensive services for example, quality occurs during service delivery, usually in an interaction between the client and the contact person from the service firm (Nick and Patrick, 2008). In this situation, the customer input becomes critical to the quality of service performance.

\section{Perishability}

The inseparability of production and consumption in turn results in an inability to store service capability. Perishability means that services cannot be produced in advance, inventoried and later made available for sale. Services are performance that cannot be stored (Parasuraman et al., 1985).

\subsection{Public Service Delivery}

Public service delivery is the most important element of NPM driven PSRs. Akalu (2015) stated that among the factors that caused the first and second generation of reforms in developing countries to fail was the lack of emphasis on public service delivery. Yonatan (2010) also stated the major failure of the first generation reform of 1980 s and 1990s was to focus merely on reforms in the organization rather than on public service delivery, due to the pressure of crisis and structural adjustments. The third generation reforms emphasized on public service delivery based on the lessons learnt from the previous reforms. PSRs that fail to emphasize on public service delivery are unlikely to be successful. The meaning and related concepts of public services are discussed briefly as follows (Mintesnot, 2016). Public services is a term usually employed to mean services provided by the government to the citizens, either directly (through the public sector) or indirectly by financing the private provision of the services, and it is associated with a social consensus (usually expressed through democratic elections) that certain services should be available to all, regardless of their income (Rida et al., 2012). According to Zertu (2010), for service organization or service provider, satisfying or fulfilling the expectation of its customer is one of the major goals. It is stated in the article of Joan and Joseph, (2002) that for service providers, their main task is to reduce the mismatch or gap between what the organization planned to provide and what the end users (customers) are expecting to benefit from the service they have been offered.

\subsection{Service Quality}

Without any doubt, service quality is very important component in any service delivery activity. This is especially so, to service provider a customer's evaluation of service quality and the resulting level of satisfaction are perceived to affect bottom line measures of organization's success. Customer expectations are beliefs about a service that serve as standards against which service performance is judged; which customer thinks a service provider should offer, rather than on what might be on offer (Parasuraman et al., 1985). To understand what service quality is, we need to understand what Quality is and it's concept as a whole. Understanding the term "Quality" will reveal that the concept has been defined in many different ways and with different emphasis by the various quality gurus and writers on the subject. Quality is an elusive and indistinct construct. Parasuraman et al., (1985) has defined service quality as the ability of the organization to meet or exceed customer expectations. It is the difference between customer expectations of service and perceived service. Perceived service quality results from comparisons by customers' expectations with their perceptions of service delivered by the suppliers (Desta, 2008). If expectations are greater than performance, then perceived quality is less than satisfactory and hence customer dissatisfaction occurs (Parasuraman et al., 1985).

\section{Service Quality Models}

There are various models to measure service quality and customer satisfaction. The major models developed by various leading scholars are discussed here under.

\section{Service quality model (Gronroos)}

Gronroos (2007) relates definition of service quality with the result of the comparison that customers make between their expectations about a service and their experience of the way the service has been performed. He also stated that services are produced, distributed, and consumed in the interaction between the service provider and the service receiver. Accordingly, services must be viewed from an interactive perspective. The model proposed by Gronroos (2000), focuses on the role of technical quality (or output) and functional quality (or process) as occurring prior to and resulting in outcome quality. In the model, technical quality refers to what is delivered to the customer while functional quality is regarding with how the end result of the process was transferred to the customer. The model states that the consumer is not interested only on what he/she receives as an outcome of the production process, but also on the process itself. The perception of the functionality of the technical outcome (technical quality) is a major determinant of the way he/she appreciates the effort of the service provider.

Five Gaps model: The Gaps Model was developed by Parasuraman et al. (1985) based on results from empirical research. The in-depth study of service businesses consisted of personal interviews with executives from various areas of the firms, to understand their perception of service quality expectations versus focus customer groups. The Gaps Model identifies five organizational gaps within the process of service design and delivery that causes 
deficits in quality, leading to unsatisfied customers. (Parasuraman et al., 1985:43)

Gap 1, is the distance between what customers expect and what managers think they expect - survey research is a way to narrow this gap.

Gap 2, is the distance between management perceptions and actual specifications of the customer "s experience. Managers need to make sure the organization is defining the level of service they believe is needed.

Gap 3, is the distance from the experience specification to the delivery of the experience. Managers need to audit the customers"experience that their organization currently delivers in order to make it live up to the specification. Gap 4, is the distance between the delivery of the customer experience and what is communicated to customers. All too often the organization exaggerate what will be provided to customers, or discuss the best case rather than the likely case raising customer expectations and harming customer perceptions.

Gap 5, the distance between the customer's perception of the experience and the customer's expectation of the service. Customers"e expectations have been shaped by word-of-mouth, their personal needs and their own past experiences (Schiffman and Kanuk, 2005).

SERVQUAL model: The SERVQUAL model was first introduced by Parasuraman and colleagues in 1985 in the United States. Since its inception SERVQUAL has become a popular method for measuring service quality (Saunders et al., 2009). It involves measuring both customer perceptions and expectations of service along key service quality dimensions. The SERVQUAL tool has brought an extensive recognition as the best tool to investigate, review and measure the quality of services and hence, customer satisfaction (Tessa et al., 2011). As a result, it is an extremely supportive instrument but it cannot be implemented in the same way in all of the various organizations. Therefore, it needs modification depends on the situations.

These dimensions have experienced several modifications and many authors came up with various dimensions related to SERVQUAL which has been recognized and implemented in various organizations. A research study that was recognized as one of the most wide ranging studies in the area of service quality was conducted by Parasuraman et al. (1985). It was offered as a multidimensional construct. In their original formulation Parasuraman et al., (1985) identified ten components of service quality; Reliability, responsiveness, competence, access, courtesy, communication, credibility, security, understanding/knowing the customer, tangibles. In their work of 1988, these components were collapsed into five service quality dimensions. According to Tessa et al., (2011) those service quality dimensions with its unique features are given below:

Reliability: the ability to carry out the promised service dependably and accurately.

Responsiveness: the willingness to support or help the customer and provide prompt service. It emphasizes special treatment and promptness in dealing with customer query, complaints and problems. It is communicated to customers according to the length of time they have to stay in order to get support, answer their questions, or special attention to their problems.

Tangibility: referring to the appearance of physical facilities, equipment and appearance of personnel or staffs. It represents the physical image of the service that the customer will use to evaluate service quality.

Assurance: referring to the knowledge and courteousness of the staff and their ability to entertain trust and confidence. Assurance is significant for services that customers perceive as high risk or where they feel doubtful about their ability to measure outcomes.

Empathy: providing individualized attention provided to customers. The essence of empathy is conveying, through personalized or customized or individualized services that customers are unique and special and their needs are specified. It was concluded that SERVQUAL is the best model to measure service quality in the public service (Tessa et al., 2011). Moreover, the SERQUAL (Parasuraman, 1988) approach has been the most popular method for choosing because it is quite complete measure for all service organizations. Therefore, this research bears on these conclusions and adopts SERVQUAL model to assess the customer satisfaction on service delivery of public service organizations in Dire Dawa Administration.

\subsection{Empirical literature}

The study conducted by parasuraman et al, (1985) resenting the five-dimensions of SERVQUAL on quality of service provided by the clinic at the University of Houston Health Center. Patients were found to be generally dissatisfied with the five dimensions of SERVQUAL. The highest dissatisfaction was felt with assurance. On the other hand, tangibles and empathy exhibited the lowest levels of dissatisfaction. Using the SERVQUAL approach, Minazzi (2008) carried out a study to assess customer satisfaction within the public sector across a range of Scottish Councils services. In the library service, the analysis of gap scores revealed that tangibles and reliability had negative gaps which indicate that customer expectations were not met. On the other hand, responsiveness and assurance were positive implying that customer expectations were actually exceeded by the service provided.

Chingang, et al., (2010) carried out a research to identify management and customer perceptions of service quality practices in the Malaysian Public sector. It is important to note that whereas the SERVQUAL model focused on identifying "gaps" between expectations and actual delivery, their dimensions identified by Parasuraman et al. (1985). Their study looked at the perceptions of management and customers, thereby excluding 
the views of Frontline Employees (FLE). In another study, Mohamad et al (2009) assessed service quality and client satisfaction in a public sector department in Malaysia. They adopted the three components model of Rust and Oliver (service product, service delivery and service environment). They found that all three dimensions were positively related to customer satisfaction. However, service environment and service delivery were not significantly related to customer satisfaction.

Service product on the other hand was significantly related, and as such a significant predictor of customer satisfaction. Also in a study conducted by Douglas and Connor (2003), to assess service quality provided by an income tax payment department in Malaysia, they found that significant gaps existed between the expectations of the income taxpayers and the services they accepted such as reliability, responsiveness and empathy. These three were higher than the tangibles and assurance dimensions. However, overall service quality was found to be highindicating that the zone of tolerance exists as the taxpayers were willing to compromise with quality. Furthermore, IIhaamie (2010) conducted a study in three hundred public organizations in Malaysia. Respondents were asked to allocate hundred points (100) to the five service quality dimensions. The results were as follows - tangibles (21.10); reliability (20.63); responsiveness (20.51); assurance (20.05) and empathy (18.11). The conclusions were that service quality impacted on customer satisfaction as indicated by the scores of the dimensions, but tangibles happened to be the most important determinant, with empathy being the least.

The research conducted by Owino, (2013) on the influence of service quality and corporate image on customer satisfaction among university students in Kenya revealed four dimensions of service quality as human elements reliability, service blue print, human element responsiveness and non-human elements. The four dimensions had Eigen values greater 1 and Cronbach's alpha greater than 0.700 , they were considered adequate and reliable in explaining variations in customer satisfaction. Human elements reliability with a Cronbach's alpha of 0.931 and corporate image with Cronbach's alpha of 0.909 , had the greatest influence on customer satisfaction. The study established the existence of a significant difference in the dimensions of service quality that influence customer satisfaction between public and private university students along the four service quality dimensions. A statistically significant relationship was established between service quality and customer satisfaction.

The relationship between service quality and corporate image was statistically significant. Further findings revealed that a statistically significant relationship existed between corporate image and customer satisfaction. A test of the mediated relationship confirmed that the relationship between service quality and customer satisfaction was partially mediated by corporate image, an observation that adds to existing literature by uncovering the mediating effect of corporate image on the relationship between service quality and customer satisfaction amongst university students According to Rida, et al (2012), assessment of service quality expectations and perceptions investigated the study has proved to be reliable in the government and private service setting. The service quality gaps indicated that the government and private service department was failing to meet the expectations of their customers

\section{Research Conducted in Ethiopia}

There are many research works done related with this study in Ethiopia. However the researchers try to see three of them which are more related to the topic. The titles with their objectives and major findings are discussed below to have an insight about the studies. The first work is done by Amhara Management Institute (2014) with a title of "Service Delivery and its Impact on Customer Satisfaction in Amhara National Regional State: a case study of Hospitals, Courts, Industry and Urban Development, and Trade and Transport". The main purpose of the study is to examine the level of service delivery quality on customer satisfaction with the following specific objectives:

To assess the level of customer satisfaction on public service delivery process as measured in terms of tangibles, responsiveness, assurance, reliability and empathy; to identify the gaps in the existing service delivery process. Based on these objectives, the study found that majority of respondents was dissatisfied with the service delivery process available in the selected public service organizations in Amhara National Regional State. Moreover, among the five service quality dimensions, responsiveness had lowest mean score values and also had the most significant effect on customer satisfaction, then tangibles, reliability, assurance and empathy respectively.

On the other hand, the research conducted by Tibebe (2012) on the title of "analyze whether perceived customer service directly related to customer satisfaction regarding the National Alcohol \& Liquor Factory (NALF) customers in Addis Ababa" indicated that five service quality dimensions were positively related to overall service quality and are indeed drivers of service quality which in turn has an impact on customer satisfaction. The study findings also indicated that all the standardized coefficients relating the service quality dimensions to overall service quality and to customer satisfaction have the expected positive sign and are statistically significant.

The impact of five service quality dimensions on customer satisfaction was significant in all factors of service quality. More specifically, customers indicated high satisfaction with the five dimensions of service quality examined in the study (Reliability, Responsiveness, Empathy, Assurance, and Tangibles). In this regard it was interesting to note that the dimension of- Responsiveness and empathy had the lowest mean ratings; however, the correlation between Assurance and customer satisfaction was the highest, which implies that improvement in employees Assurance is an important issue that requires attention. The research also concluded that service quality 
can be used to predict customer satisfaction.

Another research conducted on critical factors of customer satisfaction in Ethiopian service sector by Rajasekhara and V.S. Malglale, (2011) showed that 36\% customers of Ethiopian service sector were dissatisfied with employees' interaction skills. Furthermore another $47 \%$ of the customers were also disappointed with service delivery system and 52 and $61 \%$ customers were not pleased with the service recovery process and complaint handling procedure, respectively. And $49 \%$ of the customers expressed overall dissatisfaction on the services provided by Ethiopian service sector. Besides $94 \%$ respondents robustly acknowledged Ethiopian service sector is improving immensely in providing all kinds of services. Because of significant dissatisfaction percentage levels among customers, sector's think tank has the opportunity to seriously evaluate its existing activities, procedures, programs related to service interaction, delivery and recovery process, complaint handling and other areas which crafted unhappiness in the market.

\subsection{Conceptual Framework}

The aim of this section is to summarize the idea about past literature and to bring out the contributions for this study area. Thus this part starts with the idea generated and the contribution follows. The general idea from the past literature is that there is a relationship between customer satisfaction and service quality; also that service quality could be evaluated with the use of five service quality dimensions and the most useable is the SERVQUAL scale. A questionnaire for customers and employees has been developed based on the dimensions of the service quality in the public service organizations.

\section{Independent Variables Dependent Variable}

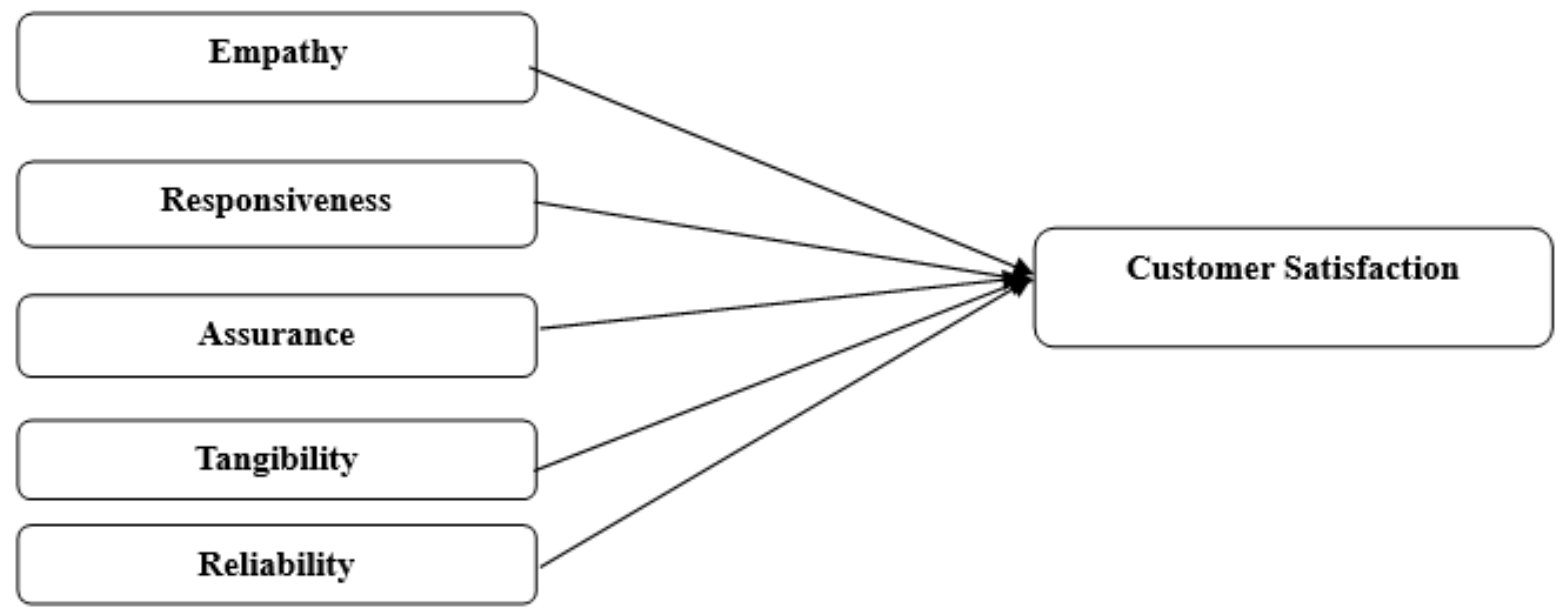

Source: Research Model adapted from Parasuraman, et al, 1988

\section{Research Methodology}

The study employed a cross-sectional field survey method to assess the level of customer satisfaction on service delivery of public service organizations based on respondents' attitudes. In cross-sectional field survey method, relevant data were collected at one point in time at public service organizations by distributing questionnaires to customers. In this method, independent and dependent variables were measured at the same point in time using a single questionnaire. Along with the cross sectional nature of this study, the study employed descriptive research method to analyze the data collected from customers. This method enabled the researchers to describe the existing situation under study. It was used to describe the service quality dimensions that would lead to customer satisfaction. It was also used for detail description of the findings displayed in tables and charts as well as for developing inferences on the level of customer satisfaction on service delivery. Moreover, the study used explanatory study design, to explain, understand and control the relationship between variables.

In order to acquire the best results, the researchers used the way of triangulation. A combination of both qualitative and quantitative method was employed in this research. The researchers believed that using these two methods simultaneously enabled them to tackle the research problem under study. Mixing different methods can strengthen a study; it would be a great advantage when the findings of one were corroborated by the other. Therefore, quantitative approaches have been used for the data collected from respondents through questionnaire. To provide a more complete picture of evaluation, the study also applied qualitative approaches for the data gathered from interviews and secondary sources.

To attain the objectives of the study, data were collected from both primary and secondary sources. The primary data were collected from customers, employees and heads of institutions. Secondary data were also collected from websites, annual reports, publications, journals, and other reform documents of the respective 
organizations.

\subsection{Sampling Technique and Sample Size}

The researchers selected seven public service institutions using purposive sampling technique. These institutions were: Revenue Authority, Water and Sewage Authority, Land Development and Management Bureau, Dilchora Referral Hospital, Dire Dawa First Instance Court, Ethiopian Electric Utility, and Kebele 06 Administration. The selection of these institutions was on the basis of some criteria like high number of customers, large budget allocation, and their importance in the social and economic setting of the city administration. The target population of the study was the total number of customers who have accessed services in the selected seven public service institutions from July, 2015 to July, 2016 in Dire Dawa Administration. The total population of these customers was about 27,458 . This figure was computed by summing up the estimated average number of monthly customers of the selected public service institutions, except for Dilchora Referral Hospital whose estimated average number of customers was taken on a daily basis for sample size determination. The other target population was the employees of the selected public service institutions. These were experts or officers who have direct or frequent contact with the customers. The total population of these employees was 529. The choice of past customers/clients was informed by the fact that satisfaction with the service delivery can properly be assessed after one has fully or to a greater extent experienced the service. In effect, care was taken not to select very old or past clients as memories of their experiences might have been faded. The total population of customers and employees from the selected public service institutions were 27,458 and 529 respectively. A sample of 870 customers and 206 employees were taken based on the minimum precision (0.01). The study used systematic random sampling methods to select customer and employee respondents. In a nut shell, out of the sample frame of 27,987, a sample size of 1,076 respondents was selected. This was to achieve a great degree of representativeness of the responses of respondents. Purposive sampling technique was used to select heads of the institutions and/or core process owners for interview. They were those who sometimes interacted with the customers and as such had some indepth knowledge and better understanding about the concerns and needs of the customers. The total population of these informants was seven, and all of them were selected for interviewing as the population was not large.

\subsection{Method of Data Collection}

Data for this study were collected through Document review, Structured Questionnaires, Semi-structured interviews. Documentation involves collecting information and data from existing surveys, reports, journals and any relevant publications. The Structured Questionnaire which was consisting of 26 items was primarily developed in Amharic language version to make it easily understandable by respondents and then converted into English language for analysis purpose. Both open ended and close ended questions were designed to collect quantitative data. The questionnaire had two major parts. The first part was about the demographic characteristics of respondents. The second part was designed to measure the service delivery processes of the selected public service organizations by using the SERVQUAL model as proposed by Parasuraman et al (1988), comprising five components of service quality. The components were Empathy, Responsiveness, Assurance, Tangibility, and Reliability. The researchers used a five-point Likert scales, representing a range of attitudes from strongly disagree (1) to strongly agree (5), to measure the variables. The dimensions of service quality delivery (independent variables) were measured using the SERVQUAL model, whereas the customer satisfaction (dependent variables) were measured using a single scale item which comprised a range of scales from very low (1) to very high (5). Semi-structured interviews were also conducted using interview guide with the selected key informants to obtain more detailed information, in such a way that the researchers probed by raising some related questions for further explanation. This was intended to get further information which could answer the research questions.

\subsection{Data Analysis and Presentation}

Quantitative data analysis was done by the use of the Statistical Package for Social Scientists (SPSS) software IBM version 21 and STATA version 12. Reliability method, descriptive statistics, Spearman's correlation, mean values, frequency distribution and percentages were used to analyze the responses of respondents. Presentation devices such as tables, graphs, and charts were also used to analyze and present the results. Qualitative analysis was done by narrating the views and themes based on the research objectives, research questions and the issues discussed.

\subsection{Pilot Survey/ Pre-testing}

A pre-testing of the questionnaires was done at Kebele 03 administration and Dire Dawa Public Service and Human Resource Development Bureau since they were not part of the scope of the study. This was done from May 9 to May 13, 2016. Accordingly, the final questionnaires were pre-tested to a sample of 20 customers and 10 employees selected from the institutions by simple random method. From the pre-test study it was observed that some of the questions proved redundant, the order of Likert Scale and how they were to be answered was not clear, and as a 
result respondents had difficulty in answering them. Consequently, these questions were revised based on the feedbacks obtained from the pilot survey.

\section{Results and Discussion}

There are different methods of reliability test, for this study Cronbach's alpha is considered to be suitable. Accordingly, the results of Cronbach's alpha reliability test showed that all the values were above 0.80 indicating that the instrument were reliable. As described by Andy (2006) the values of Cronbach's alpha around 0.8 is good. The alpha values in this study are above 0.8 and therefore it is good.

Table 4.1. Results of Reliability Test

\begin{tabular}{|l|r|r|r|}
\hline Dimensions & Cronbach's Alpha & Cronbach's Alpha Based on Standardized Items & N of Items \\
\hline Empathy & 0.907 & 0.910 & 5 \\
\hline Responsiveness & 0.884 & 0.903 & 5 \\
\hline Assurance & 0.878 & 0.906 & 6 \\
\hline Tangibility & 0.849 & 0.849 & 4 \\
\hline Reliability & 0.935 & 0.935 & 6 \\
\hline All variables & 0.970 & 0.974 & 27 \\
\hline
\end{tabular}

Source: survey result, 2016

\section{Background Information of Respondents}

Out of the 870 questionnaires distributed, 866(99.5\%) questionnaires were returned and found to be valid for analysis. The demographic characteristics include: sex, age, educational status, occupation of respondents, residence of respondents, and frequency of office visit. This aspect of the analysis deals with the personal data on the respondents of the questionnaires given to them. The response rate was $99.5 \%$ (866). From 866 study participants, $544(62.8 \%)$ were males and $322(37.2 \%)$ were females. This indicates that the males $(62.8 \%)$ respondents were more than that of female respondents $(37.2 \%)$. When we look at the age distribution of respondents, $263(30.4 \%)$ of the respondents were between the age of 15 to 30 years, $468(54 \%)$ of them were between 31 to 45 years. $105(12.1 \%)$ of the respondents were between the age of 46 to 60 years and the remaining $30(3.5 \%)$ of them were above 61 years. This shows that majority of respondents $(96.5 \%)$ were in between 15 to 60 years, which implies most of the respondents were in the productive age groups.

Similarly, regarding the educational distribution of respondents, $24(2.8 \%)$ were illiterate, $21(2.4 \%)$ were able to read and write, $150(17.3 \%)$ were elementary level education (grades 1-8), 326 (37.6\%) completed high school education (grades 9-12), 185 (21.4\%) had diploma, 145 (16.7\%) had first degree and the remaining 15 $(1.7 \%)$ had other qualifications. This implies that most of the respondents were literate and able to comment on service delivery. As far as the occupation of respondents were concerned, 10 (1.2\%) were farmers/pastoralist, 188 (21.7\%) were government employees, 435 (50.2\%) were self-employed, 29 (3.3\%) were daily laborers, 52 (6\%) were unemployed and $152(17.6 \%)$ respondents were fallen under other activities. Out of the 435 self-employed respondents, $22(5.1 \%)$ were engaged in hotel/restaurants, $38(8.7 \%)$ in construction sector, $43(9.9 \%)$ in production industries, $192(44.2 \%)$ in trade, and 111 (25.5) engaged in service sector, and the remaining $29(6.7 \%)$ were engaged in other activities. This implies that about half of the respondents were self-employed followed by government employee. Regarding the residence of the respondents, majority $845(97.6 \%)$ were urban residents, and the remaining $21(2.4 \%)$ respondents were from rural areas. Regarding office visit of respondents, $490(56.6 \%)$ of respondents indicated that they visited offices monthly, $108(12.5 \%)$ visited offices weekly, $99(11.4 \%)$ have contacted offices in a daily manner, 79 (9.1\%) visited offices- bi-annually, 41(4.7\%) respondents visited offices annually, and the remaining $49(5.7 \%)$ responded that they visited offices out of the above schedule. This indicates $56.6 \%$ of the respondents were familiar with and able to comments the service delivery system of the selected organizations.

\section{Background Information of Employee Respondents}

Out of the 206 questionnaires distributed, 190 questionnaires were returned for analysis representing $92 \%$. The demographic characteristics include: sex, age, level of education, years of services and position of employees. The table below shows the details of background information of the employee respondents.

The results show that $55.85 \%$ and $44.15 \%$ of the respondents were males and females respectively. From this, it is possible to figure out that the proportion of male respondents is slightly greater than that of females. Regarding the age distributions of the respondents, $49.1 \%, 19.9 \%, 17.5 \%, 11.1 \%$ were in the age group between $26-35,36-$ $45,18-25$ and $46-55$ years of age respectively. While only $2.3 \%$ of them were above 55 years of age. This indicates that $69 \%$ of the employees were in the age group between 26 to 45 years. Concerning the education background of the respondents, 55\% had first degree, 19.6\% had diploma, $11.1 \%$ completed high school, 5.8\% had second degree and the remaining $8.5 \%$ had other qualifications. This implies that more than $60 \%$ of the respondents had first degree and above. Similarly, the service experiences of respondents, 32.1\% between $1-5$ years, $28.3 \%$ were more than 10 years, $24.6 \%$ were between $6-10$ years and the remaining $15 \%$ had less than one year service experiences. This indicates that majority of respondents had 6 and above (52.9\%) years of service 
experiences. Lastly, regarding the position of employees, $52.7 \%$ were experts, $28.5 \%$ were senior experts, $8.1 \%$ were junior experts, and the remaining $10.8 \%$ were other than listed. This implies that $81.2 \%$ of the employees' positions were classified as experts and above.

\subsection{Level of Satisfaction}

\section{Level of Customer Satisfaction}

Customer satisfaction is the degree to which customer perceives that an individual, firm or organization has effectively provided a product or service that meets the customer's needs in the context in which the customer is aware of and / or using the product or service (Cengiz, 2010). Accordingly, all 831 customer respondents were asked to assess their overall level of satisfaction with the ongoing services in the selected public service organizations in terms of showing their levels of agreement and disagreement using 5 category Likert-scale ( 1 very low to 5 very high). The result obtained from responses of respondents show that, $8.42 \%, 21.06 \%, 27.80 \%$, $31.05 \%$ and $11.67 \%$ respondents expressed their level of satisfaction as very low, low, medium, high and very high respectively. This implies that, majority $(70 \%)$ of sample respondents had moderate and above satisfaction level with the service delivery statuses of the selected public service organizations. In contrast, about $30 \%$ of respondents reported low level of satisfaction.

\section{Employee`s Perception on Overall Satisfaction Level}

Similarly, Employees responses about overall satisfaction on service delivery of their respective institution were presented in table 4.2 below

Table 4.2. Employee`s perception on Overall Satisfaction Level

\begin{tabular}{|l|l|l|}
\hline Item & Frequency & Valid Percent \\
\hline low & 23 & 12.8 \\
\hline Medium & 45 & 25.1 \\
\hline high & 85 & 47.5 \\
\hline very high & 26 & 14.5 \\
\hline Total & 179 & 100.0 \\
\hline
\end{tabular}

Source: survey result, 2016

As indicated in table above, Employees rated the overall satisfaction level on service delivery as very low $(0 \%)$, low (12.8\%), medium (25.1\%), high (47.5\%) and very high (14.5\%). This implies that, majority $(62 \%)$ of respondents had rated satisfaction level of the service delivery as high. Only about $12.8 \%$ of respondents reported low level of satisfaction.

Table 4.3: General Customer Satisfaction by Service delivery Dimensions

\begin{tabular}{|l|l|l|l|}
\hline Item & Mean & Std. Deviation & N \\
\hline General Satisfaction & 3.16 & 1.14 & 824 \\
\hline Empathy & 3.63 & 1.21 & 824 \\
\hline Responsiveness & 3.24 & 1.32 & 824 \\
\hline Assurance & 3.49 & 1.17 & 824 \\
\hline Tangibility & 3.37 & 1.17 & 824 \\
\hline Reliability & 3.22 & 1.27 & 824 \\
\hline
\end{tabular}

Source: survey result, 2016

To support the above results, mean scores (where scores approached to 1 indicates the worst (minimum) score while scores approached to 5 shows best (maximum) satisfaction level) were computed. Accordingly, the mean scores of average satisfaction computed from the five dimensions-Empathy, Responsiveness, Assurance, Tangibility, and Reliability- and general satisfaction were 3.42 and 3.16 respectively. The average satisfaction has greater mean score than that of the overall satisfaction. These results indicated that mean score was better when it was asked in a disaggregated manner than asking in a question directly. In conclusion, the general customer satisfaction mean scores in the administration for all dimensions showed moderate. More specifically, Empathy, Responsiveness, Assurance, Tangibility, and Reliability accounted for average scores of 3.63, 3.24, 3.49, 3.37, and 3.22 respectively. 
Table 4.4. : General Customer Satisfaction Level by Organizations

\begin{tabular}{|c|c|c|c|c|c|c|c|c|}
\hline \multirow{2}{*}{$\begin{array}{l}\text { Name of the } \\
\text { Institution }\end{array}$} & \multicolumn{5}{|c|}{ General/Overall Satisfaction } & \multicolumn{2}{|l|}{ Mean Score } & \multirow[t]{2}{*}{ Total } \\
\hline & $\begin{array}{l}\text { Very low } \\
(\%)\end{array}$ & $\begin{array}{l}\text { Low } \\
(\%)\end{array}$ & $\begin{array}{l}\text { Med } \\
(\%)\end{array}$ & $\begin{array}{l}\text { High } \\
(\%)\end{array}$ & $\begin{array}{l}\text { Very } \\
\text { high }(\%)\end{array}$ & $\begin{array}{ll}\text { Gen. } \\
\text { mean }\end{array}$ & $\begin{array}{l}\text { Gen. Sat } \\
\text { Std. Dev }\end{array}$ & \\
\hline Land & 26 & 25 & 14 & 26 & 9 & 2.65 & 1.34 & 84 \\
\hline Revenue & 6 & 14 & 21 & 38 & 21 & 3.53 & 1.15 & 109 \\
\hline Water & 5 & 13 & 27 & 38 & 17 & 3.50 & 1.07 & 150 \\
\hline Court & 5 & 28 & 24 & 34 & 9 & 3.14 & 1.08 & 100 \\
\hline Dilchora & 0 & 16 & 37 & 43 & 4 & 3.34 & 0.79 & 148 \\
\hline Kebele 06 & 0 & 4 & 27 & 37 & 32 & 3.98 & 0.87 & 49 \\
\hline EEU & 15 & 34 & 33 & 13 & 5 & 2.58 & 1.05 & 191 \\
\hline Total & & & & & & & & 831 \\
\hline
\end{tabular}

Source: Field Survey, 2016

The table 4.4 above shows that the disaggregated customer satisfaction scores for each selected organization. Out of 84 respondents of Land Development and Management Bureau Overall Customer Satisfaction Level scores $26 \%, 25 \%, 14 \%, 26 \%$ and $9 \%$ are very low, low, medium, high and very high respectively. This implies $51 \%$ of the respondents have below moderate satisfaction level. Similarly, out of 191 respondents of EEU`s Overall Customer Satisfaction Level scores 15\%, 34\%, 33\%, 13\% and 5\% were responded as very low, low, medium, high and very high respectively. This implies $49 \%$ of the respondents have below moderate satisfaction level, whereas $51 \%$ of the respondents have moderate and above satisfaction level with the services they get from a given organization. This result is supported by the calculated mean scores of both organizations, namely Land Development and Management Bureau and EEU, with mean scores of 2.76 and 2.96 respectively. This implies that both organizations have below moderate satisfaction level. On the other hand, the remaining organizations such as Revenue Authority, Water and Sewerage Authority, First Instance Court, Dilchora Hospital and Kebele 06 Administration have average mean scores of 3.84, 3.79, 3.39, 3.52 and 4.26 respectively. This shows that the satisfaction level of these organizations were moderate and above.

Table 4.5. : Employees' Perception on General Customer Satisfaction Level by Organizations

\begin{tabular}{|c|c|c|c|c|c|c|c|c|}
\hline \multirow{2}{*}{$\begin{array}{l}\text { Name of the } \\
\text { Institution }\end{array}$} & \multicolumn{5}{|c|}{ General/Overall Satisfaction (\%) } & \multicolumn{2}{|l|}{ Mean Score } & \multirow[t]{2}{*}{ Total } \\
\hline & $\begin{array}{l}\text { very } \\
\text { low }\end{array}$ & low & med & high & $\begin{array}{l}\text { very } \\
\text { high }\end{array}$ & 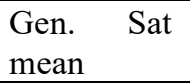 & $\begin{array}{l}\text { Gen. Sat } \\
\text { Std. Dev }\end{array}$ & \\
\hline Land & 0 & 7.14 & 35.71 & 57.14 & 0 & 3.50 & 0.65 & 15 \\
\hline Revenue & 0 & 0 & 10.71 & 57.14 & 32.14 & 4.21 & 0.63 & 29 \\
\hline Water & 0 & 13.3 & 13.3 & 66.67 & 6.67 & 3.67 & 0.80 & 33 \\
\hline Court & 0 & 18.18 & 27.27 & 27.27 & 27.27 & 3.64 & 1.12 & 11 \\
\hline Dilchora & 0 & 20.97 & 37.10 & 35.48 & 6.45 & 3.27 & 0.87 & 68 \\
\hline Kebele 06 & 0 & 0 & 8.33 & 58.33 & 33.33 & 4.25 & 0.62 & 12 \\
\hline EEU & 0 & 23.08 & 30.77 & 38.46 & 7.69 & 3.64 & 0.95 & 22 \\
\hline Total & & & & & & & & 190 \\
\hline
\end{tabular}

Source: Field Survey, 2016

Table 4.5 shows that employees responses about general satisfaction level on service delivery of the selected institutions were 3.50, 4.21, 3.67, 3.64, 3.27, 4.25 and 3.64 for Land Development and Management Bureau, Revenue Authority, Water and Sewerage Authority, First Instance Court, Dilchora Hospital, Kebele 06 Administration and EEU respectively. This implies that the responses of employees in all the selected institutions indicated that the general level of customer satisfaction on service delivery were moderate and above unlike that of customers.

\subsection{Evaluation of Service Delivery Standards/Dimensions}

The various perceptions under each service delivery dimensions were grouped into 5 constructs and calculated its individual average to get composite scores. The study used the modified version of SERVQUAL model as proposed by Parasuraman et al., (1998) which involves five dimension of service delivery standard measurement and the composite scores were calculated. Empathy includes customer respect, understanding customer need, giving due attention to customer needs, conducive waiting area and Serving with smiles. Res4.2ponsiveness involves fast response, customer oriented service, giving timely service, grievance handling system and handling grievances appropriately. Assurance also entails knowledge of employees about service, adequate information about the service, knowledge of employees about the institution`s system, problem solving capacity, employees capacity to serve, employees motivation and service mentality. Similarly, tangibility includes service delivery as per expectation, existence of adequate employees, clear and communicated pre-conditions and convenient working place. Finally, reliability includes keeping promise, free from corruption and rent seeking, accessibility of service, 
provision of services as per standards and fair service provision. The table below shows the aggregated results of the service delivery measurement dimensions.

Table 4.6 Average scores of the five service delivery dimensions for the entire sample

\begin{tabular}{|l|l|l|l|l|l|l|}
\hline \multirow{2}{*}{ Dimensions } & \multicolumn{2}{l|}{ Customers } & \multicolumn{2}{l|}{ Employees } & \multirow{2}{*}{ Max } \\
\cline { 2 - 6 } & Mean & Std. Dev. & Mean & Std. Dev. & & \\
\hline Empathy & 3.54 & 1.09 & 4.28 & 0.52 & 1 & 5 \\
\hline Responsiveness & 3.21 & 1.19 & 3.9 & 0.82 & 1 & 5 \\
\hline Assurance & 3.44 & 1.08 & 4.2 & 0.59 & 1 & 5 \\
\hline Tangibility & 3.32 & 1.06 & 3.67 & 0.84 & 1 & 5 \\
\hline Reliability & 3.19 & 1.14 & 3.83 & 0.79 & 1 & 5 \\
\hline
\end{tabular}

Source: survey result, 2016

Table 4.6 shows the aggregated mean scores of service delivery measurement dimensions of selected public service organizations in Dire Dawa Administration. Accordingly, Empathy has the highest mean score of 3.54, followed by Assurance, Tangibility and Responsiveness with mean scores of 3.44, 3.32 and 3.21 respectively. The least important dimension according to the finding is Reliability with a mean score of 3.19. These findings indicate that the composite mean scores are all less than 4 for each service measurement dimension and yet the maximum possible score is 5 . The mean composite scores are above average but less than the mean maximum score. The findings of the study indicate that currently the service delivery standard as evaluated by the customers found to be moderate. The findings indicate further that customers viewed empathy to play a key role in determining the standards of service received whereas reliability plays a least role. On the other hand, the employees' responses on the average mean score of service delivery dimensions for the selected organizations empathy has still the highest mean score of 4.28 and assurance with a mean score of 4.20 , followed by responsiveness, reliability, and tangibility with mean scores of 3.9, 3.83, and 3.67 respectively. The table also shows that the employees` mean scores of all service delivery dimensions were greater than that of customers. This indicates that there is quite deviation between customers and employees.

\subsection{Major Challenges that prevailed in the Service Delivery Process of Public Service Organizations}

The major challenges in service delivery of Dire Dawa Administration obtained from customers, employees, KII, and content analysis were:

- Lack of skilled and experienced leadership, instability of officials, inability to lead and make decisions strategically, frequent meetings on working hours, lack of timely response and keeping appointments to provide services, inconsistent follow up and monitoring, absence of regular consultation with customers and stakeholders, prevalence of corruption and rent seeking activities and behavior, turnover, inadequate technical capacity and skills, lack of motivation and service mentality, unethical behavior, lack of empowerment and problem solving capacity were the major challenges.

- Lack of customer oriented services, ineffective automation, absence of timely revision of rules and regulations; frequent interruption of networks and electric power, lack of cooperation and integration among stakeholders, inefficient and inappropriate grievance handling systems in place.

- Lack of equipment and machineries, inaccessibility of selling registration machines, inadequate medical facilities, inadequate supply and dalliance of Meters, Fuses and Poles.

- Inappropriate referral system and overflow of customers out of catchment area, inadequate production and selling premises for micro and small enterprises, absence of decentralization of land services at kebele level, mismatch between demand and supply in water, health and electric services, as well as the structural and local development plans were among the major challenges.

- $\quad$ The pre-determined service delivery procedure, standards and change management tools lack working and implementation manuals; and different formats to put them into effect. In addition, absence of conducting customer satisfaction surveys scientifically.

\subsection{Correlation Analysis Results}

Researchers calculated Spearman's Correlation to check whether the aggregate levels of satisfaction are significantly correlated with the five dimensions of service delivery scores. As it can be presented in table 4.7, the correlation results indicate that there is significant relationship among all variables. In other words, the result shows that there is significant and positive relationship between customer satisfaction and the five service delivery dimensions (Empathy, Responsiveness, Assurance, Tangibility and Reliability). From this, one can conclude that service delivery dimensions are positively correlated with customer satisfaction, implying that they are dominant components/attributes to measure customer satisfaction. 
Table 4.7 The Spearman's correlation coefficients of the service delivery dimensions and general customer satisfaction

\begin{tabular}{|c|c|c|c|c|c|c|c|}
\hline \multicolumn{8}{|l|}{ Correlations } \\
\hline Model & & $\begin{array}{l}\text { General } \\
\text { Satisfaction }\end{array}$ & Empathy & $\begin{array}{l}\text { Responsiven } \\
\text { ess }\end{array}$ & Assurance & $\begin{array}{l}\text { Tangibil } \\
\text { ity }\end{array}$ & $\begin{array}{l}\text { Reliabilit } \\
\mathrm{y}\end{array}$ \\
\hline $\begin{array}{l}\text { General } \\
\text { Satisfaction }\end{array}$ & \multirow{6}{*}{$\begin{array}{l}\text { Correlation } \\
\text { Coefficient }\end{array}$} & 1.000 & $.688^{* *}$ & $.727^{* *}$ & $.706^{* *}$ & $.690^{* *}$ & $.768^{* *}$ \\
\hline Empathy & & $.688^{* *}$ & 1.000 & $.728^{* *}$ & $.715^{* *}$ & $.654^{* *}$ & $.697^{* *}$ \\
\hline Responsiveness & & $.727^{* *}$ & $.728^{* *}$ & 1.000 & $.750^{* *}$ & $.701^{* *}$ & $.786^{* *}$ \\
\hline Assurance & & $.706^{* *}$ & $.715^{* *}$ & $.750^{* *}$ & 1.000 & $.715^{* *}$ & $.779^{* *}$ \\
\hline Tangibility & & $.690^{* *}$ & $.654^{* *}$ & $.701^{* *}$ & $.715^{* *}$ & 1.000 & $.774^{* *}$ \\
\hline Reliability & & $.768^{* *}$ & $.697^{* *}$ & $.786^{* *}$ & $.779^{* *}$ & $.774^{* *}$ & 1.000 \\
\hline
\end{tabular}

Source: survey result, 2016

\section{CONCLUSSIONS AND RECOMMENDATIONS}

The general objective of the study was to assess the customer satisfaction on service delivery of public organizations in Dire Dawa Administration. The study used the five service delivery elements assurance, reliability; tangibility, empathy, and responsiveness to measure customer satisfaction and service delivery. The inferential statistics result indicated that the service delivery dimensions and customer satisfaction have positive correlation, depicting that the service delivery dimensions were found appropriate attributes for measuring customer satisfaction. The study concluded that the quantitative results of the general level of customer satisfaction and the service delivery dimensions were moderate. However, the position deduced from qualitative result depicted that there were major challenges in service delivery such as lack of skilled and experienced leadership, inability to lead and make decisions strategically, inconsistent follow up and monitoring, absence of regular consultation with customers and stakeholders, prevalence of corruption and rent seeking activities and behavior, lack of motivation and service mentality, ineffective automation, absence of timely revision of rules and regulations; lack of cooperation and integration among stakeholders, inefficient and inappropriate grievance handling systems, mismatch between demand and supply in water, health and electric services, and absence of conducting customer satisfaction surveys scientifically were found to be the major challenges in service delivery of the administration.

Based on the major findings and conclusions, the following recommendations were worth drawn.

- As observed from the results of study, the general level of customer satisfaction in the administration is moderate, and this means higher officials should give due emphasis for and work on the service delivery dimensions to achieve maximum level of satisfaction. Furthermore, the disaggregated results on the level of customer satisfaction particularly in Land Development and Management, and Ethiopian Electric Utility are found below average, and hence the officials of these organizations should exert more efforts to enhance their customer satisfaction levels by establishing customer service representative units which are responsible for conducting periodic customer satisfaction surveys, monitoring the service delivery processes whether services are rendered as per the set standards or not, handling customers' complaints, analyzing customers' suggestions and opinions and thereby generating alternative solutions; by empowering employees through the arrangement of various training programs on customer handling, code of conduct, and technical skills.

- As indicated in the result, the mean score value are moderate for all service delivery dimensions but with the lowest value for responsiveness and reliability dimension. Thus the service delivery process requires great attention from the administration and organizational top officials, and it will need to establish a customer handling units in each organization that facilitates customers' service delivery in accordance with the needs of customers with particular responsibility.

- The inferential statistics results of the study showed that the five service delivery dimensions and customer satisfaction are positively correlated. This means the officials of the organizations should focus and work hard on the attributes of these service delivery dimensions to enhance their respective customer satisfaction.

- The Administration should strive to solve the major bottlenecks in service delivery of each particular organization that are identified in the study by giving priority based on the urgency of the problem and its impact on customer satisfaction especially problems related to input and staffing appropriate employees.

- The Administration should design and implement continuous human resource development programs like short and middle term training programs; rewarding system, strengthen the implementation of code of conduct, anti-corruption and rent seeking mitigation strategies to alleviate the prevailing corruption and rent seeking practices, unethical behavior; and to improve service mentality.

- The Administration should appoint capable and well qualified leaders at all levels by considering the specific nature of the organizations, and should set a minimum requirement for appointing leaders and organize gap 
based consistent capacity building programs.

- The Administration should design and implement an intentional and collective approach to organize and lead all service delivery system to address public problems through building shared knowledge, designing communicable and innovative solutions, and forging consequential change.

- In a nut shell, the organizations should use the findings of this study to take measures for improving the service delivery process and thereby enhance customer satisfaction.

\section{References}

- Ahmad M. Zamil, 2011. Role of Measuring Customer Satisfaction in Improving the Performance in the Public Sector Organization. King Saud University, Kingdom of Saudi Arabia. Journal of Business Studies Quarterly 2011, Vol. 2, No. 3, pp. 32-41. ISSN 2152-1034

- Akalu Awlachew, 2015. The Effect of Service Quality on Customer Satisfaction in Selected Insurance Companies in Addis Ababa. Master's degree thesis. Addis Ababa University, Addis Ababa, Ethiopia.

- Amin, Samia and Nazmul Chaudhury, 2008. "An Introduction to Methodologies for Measuring Service Delivery in Education" in Amin, Samia, Das Jishnu and Marcus Goldstein (editors) are you Being Served? New Tools for Measuring Service Delivery, the World Bank, Washington, D.C.

- Benjamin,Amanfi, 2012. Service Quality and Customer Satisfaction in Public Sector Organizations: A Case Study of the Commission on Human Rights and Administrative Justice, Masters of Business Administration,Kwame Nkrumah University.

- Benjamin Amanfi, 2012. Service Quality and Customer Satisfaction in Public Sector Organizations: A Case Study of the Commission on Human Rights and Administrative Justice, Masters of Business Administration,Kwame Nkrumah University.

- Besley, Timothy and Maitreesh Ghatac, 2006. "Reforming Service Delivery", Journal of African

- Biljana Angelova and Jusuf Zekiri, 2011. Measuring Customer Satisfaction with Service Quality Using American Customer Satisfaction. International Journal of Academic Research in Business and Social Sciences. October 2011, Vol. 1, No. 3. ISSN: 2222-6990

- Buttle, F., 2005. Customer Relationship Management: concepts and tools. Oxford: Elsevier ButterworthHeinemann.

- Chich Jen and I-Ming Mang, 2007. The relationship between service Quality and Customer Satisfaction. Chang Chung University. Taiwan Accessed on June, 2016

- Chingang, et al., 2010. Using the SERVQUAL Model to assess Service Quality and Customer Satisfaction. An Empirical study of grocery stores in Umea.Umeå School of Business, Master's Thesis.

- Creswell, J.W., 2003. Research design: Qualitative, quantitative, and mixed method approaches, $2^{\text {nd }}$ edition Sage Publication.

- Creswell, J.W., 2003. Research design: Qualitative, quantitative, and mixed method approaches, $2^{\text {nd }}$ edition Sage Publication.

- Dawkins, P. and Reichheld F., 1990. "Customer as a Competitive Weapon," Directors and Boards, 14 (summer).

- Desta Tesfaw, 2008. Public service delivery reform and customer satisfaction: the case of social security agency (ssa) and document authentication and registration office (daro). Master`s Degree Thesis. Addis Ababa University. Addis Ababa, Ethiopia.

- Douglas, L. \& Connor R., 2003. Attitudes to service quality- the expectation gap, Nutrition \& Food Science, Vol. 33 Number 4, p.165-172.

- Dr. Abdel Fattah Mahmoud Al-Azzam, 2015. The Impact of Service Quality Dimensions on Customer Satisfaction: A Field Study of Arab Bank in Irbid City, Jordan. European Journal of Business and Management. ISSN 2222-1905 (Paper) ISSN 2222-2839 (Online), Vol.7, No.15, 2015.

- Endalkachew Abebe, 2013. Assessing the impact of Core Banking and service quality on Customer Satisfaction in Commercial Bank of Ethiopia (A case of Bishofftu Branch). Master`s Degree Thesis. Hawasa University, Hawasa, Ethiopia.

- Enyonam Afi Ako-Nai, 2011. Effect of Customer Service on Customer Satisfaction, a Case Study of FidelityBank, Adum, Kumasi. Master's degree thesis. Kwame Nkrumah University of Science and Technology. Accessed on June, 2016

- Erkan, Ali Caglar, Ufuk Kaya and Çağlar Kadir, 2014. Service Quality and Customer Satisfaction Relationship: A Research in Erzurum Ataturk University Refectory. American International Journal of Contemporary Research Vol. 4 No. 1; January 2014

- Giese, J. L. \& Cote, J. A., 2000. Defining Consumer Satisfaction, Academy of Marketing Science Review, 2000 
- Grönroos. C., 2000. A service quality model and its market application. Accessed on June, 2016

- Gronroos C., 1984. 'A Service Quality model and its marketing implications', European Journal of Marketing.18:36-44.

- Hayes, B. E., 2008. Measuring Customer Satisfaction: Survey design use and statistical analysis methods.3rd edition.

- Hermen Jan Van Ree., 2009. Service Quality Indicators for Business Support Services. Doctor of Philosophy degree Thesis. London University, England.

- HM Government, 2007. How to measure customer satisfaction. Improve the experience of customers.

- Israel Berhanu, 2015. Measuring customer satisfaction of ethiopian electric utility. Master`s Degree Thesis. Addis Ababa University, Addis Ababa, Ethiopia.

- Jayaraman Munusamy, Shankar Chelliah and Hor Wai Mun, 2010. Service Quality Delivery and Its Impact on Customer Satisfaction in the Banking Sector in Malaysia. International Journal of Innovation, Management and Technology, Vol. 1, No. 4, October 2010 ISSN: 2010-0248

- Joan L. Giese and Joseph A. Cote, 2002. Defining Consumer Satisfaction. Volume 2000 No. 1 Accessed from: http://www.amsreview.org/articles/giese01-2000.pdf

- Kindye Essa Mustofa, 2011. Effect of after sale services on customer satisfaction and loyalty in automotive industry of ethiopia. . Master`s Degree Thesis. Addis Ababa University. Addis Ababa, Ethiopia.

- Kotler P., Armstrong G., Saunders J. Wong V., 2002 Principle of Marketing, $3^{\text {rd }}$ edition, Pretence Hall Europe.

- $\quad$ Kotler, P \& Keller, K. L., 2006. Marketing Management (12th ed.). Upper Saddle River, NJ: Pearson Prentice Hall.

- $\quad$ Minazzi, R., 2008. Customer satisfaction survey in the hospitality industry: comparison of international hotel chains questionnaires. Millano: Universita IULM.

- Mintesnot Beyene, 2016. Governance and Public Service Delivery: The Case of Water Supply in Akaki Kaliti Sub-City. Master's Degree Thesis. Addis Ababa University. Addis Ababa, Ethiopia.

- Mohammed Hussen, 2008. Customer s’ Satisfaction in Land Delivery Service by Urban Local Government: a case study of bishoftu town administration. Master`s Degree Thesis. Addis Ababa University. Addis Ababa, Ethiopia.

- Nick Thijs and Patrick Staes, 2008. Customer Satisfaction Management. European institute of Public Administration. Accessed on June, 2016

- Parasuraman, A., Berry, L. L. and Zeithaml, V. A., 1985. A Conceptual-Model of ServiceQuality and Its Implications for Future-Research, Journal of Marketing, 49(4).

- Parasuraman, A., Berry, L. L. and Zeithaml, V. A., 1985. A Conceptual-Model of ServiceQuality and Its Implications for Future-Research, Journal of Marketing, 49(4).

- $\quad$ Parasuraman, A., Berry, L. L. and Zeithaml, V. A., 1988. SERVQUAL: A multiple-item scale form ensuring customer perceptions of service quality, Journal of Retailing, 64 (1).

- Parasuraman, A., Berry, L. L. and Zeithaml, V. A., 1991. Refinement and reassessment of the

- Parasuraman, A., Zeithaml, V. A., \& Berry, L. L., 1985. A conceptual model of service quality and its implications for future research, Journal of Marketing, 49, 41-50.

- PaulosChanie, n.d. The challenges of the civil service reform in Ethiopia: Initial observations.

- PaulosChanie, n.d. The challenges of the civil service reform in Ethiopia: Initial observations.

- Prabha Ramseook, 2010. Service Quality in the Public Service. University of Technology, Mauritius. International journal of management and marketing research -Volume 3 - Number 1 - 2010.

- $\quad$ Rida Khurshid, Dr. Hummayoun Naeem, Sana Ejaz, Faiza Mukhtar, Taha Batool, 2012. Service Quality and Customer Satisfaction in Publice Transport Sector of Pakistan: An Empirical Study. Master`s degree thesis. Fatima Jinnah Women University, Rawalpindi, Pakistan. International journals of Economics and Management Science Vol. 1, No. 9, 2012, pp. 24-30.

- $\quad$ Robert V. Krejcie, Duluth Daryle W. Morgan, 1970. Determining Sample Size for Research Activities.Texas A. \& M. University: University of Minnesota.

- Saunders, M., Lewis P. and Thornhill A., 2009. Research Methods for business students4th edition Pearson education limited

- Saunders, M., Lewis P. and Thornhill A., 2009. Research Methods for business students4th edition Pearson education limited

- Schiffman, G.L. and L.L. Kanuk, 2005. Customer Behavior. Prentice-Hall of India Private Limited, New Delhi, pp: 14-15.

- Schiffman, G.L. and L.L. Kanuk, 2005. Customer Behavior. Prentice-Hall of India Private Limited, New Delhi, pp: 14-15.

- Schmidt and Stricklan, 2000. Client Satisfaction Surveying: Common Measurements Tool, Canadian Centre 
for Management Development November 2000.

- Simon Gyasi Nimako and Foresight Kofi Azumah, 2009. An Assessment of Customer Satisfaction with Service Delivery of Mobile telecommunication Networks in Ghana. Master Thesis. Lulea University of Technology. ISSN: 1653 - 0187

- $\quad$ Spreng, R.A., and Mackoy, R.D., 1996. An Empirical Examination of a Model of Perceived Service Quality and Satisfaction. Journal of Retailing, 72.

- $\quad$ Spreng, R.A., Mackenzie, S.B. and Olshavsky, R.W., 1996. A Re-examination of the Determinant of Customer Satisfaction: Journal of Marketing.

- Taati Rad, 2011. A Study of silent Customers, International Conference on Management (ICM) Proceeding, 790.

- Tamirat Gezahgn, 2008. Measuring Level of Customer Satisfaction in Multimodal Transport Service. The Case of Ethiopian Shiping and Logistics Services Enterprise. Master`s Degree Thesis. Addis Ababa University. Addis Ababa, Ethiopia.

- Tessa Bold, Jakob Svensson, Bernard Gauthier, Ottar Mæstad and Waly Wane, 2011. Service Delivery Indicators: Pilot in Education and Health Care in Africa. Annual Report. Accessed on June, 2016

- Tibebe Zeleke, 2012. Impact of service quality on customer satisfaction at the public owned National Alcohol and Liquor Factory. Master's Degree Thesis. University of South Africa, South Africa.

- Wilson, A., Zeithaml, V., Binter, M. and Gremler, D., 2008. Service Marketing: Integrating Customer Focus across the Firm, McGraw-Hill, London.

- Yonatan Gebre, 2010. Customers' Perception of Service Quality in Ethiopia banking sector: An Exploratory study. Master`s Degree Thesis. Addis Ababa University, Addis Ababa, Ethiopia.

- Yosef T., 2011. A Study of the Civil Service Reform in Adama city Administration: Regional State of Oromia, (MPA). Addis Ababa University: Addis Ababa.

- Yuan Pei, 2013. Does Service Quality and Customer Satisfaction Effect Customer Loyalty? A Case Study of a Chinese Electric Appliance Chain Rerailer. Master's degree thesis. Accessed on June, 2016

- ZerihunDuressa, 2014. Transformational leadership and its Applications in the public service organizations of Ethiopia, Addis Ababa.

- Zeritu Fikre, 2010. Service delivery and customer satisfaction: (the Case of Ethiopian Electric Power Corporation Eastern Addis Ababa Region Customer Service Centers). Master`s Degree Thesis. Addis Ababa University. Addis Ababa, Ethiopia. 